\title{
CHARMS IN THE CONTEXT OF MAGIC PRACTICE. THE CASE OF SLOVENIA
}

\section{Monika Kropej}

In Slovenia, charms or invocations are one- or two-strophe formulae that the medicine man or woman used at addressing the powers beyond to procure healing or to influence certain natural processes. They are as if a bridge between this world and the other, helping achieve to something on clearly supernatural or magical grounds. The following paper provides a brief insight into magical folk traditions as preserved in Slovene oral and written sources. The present article gives a short overview of contemporary magical practices in Slovenia, introducing a healer with inherited gift and words and her usual healing methods. I will also present a systematisation of Slovenian invocations with text samples and some cosmological principles as reflected in charms.

\section{MAGICAL PRACTICES IN SLOVENIA}

Slovenian folk tradition is rich and diverse in magical practices. According to older sources, wizards and witches were mythological and demonic creatures similar to kresnik, benandant, vedomec, lamia, etc. In addition to such folklore, however, some sources maintain that some people could learn witchcraft as a profession. Records indicate that magic was generally performed sympathetically, analogously, by the rule pars pro toto with the help of apotropaic acts, water, medicinal herbs and potions. Slovenian sorcerers mastered spells and ways of conjuring and adjuring. With help from books on black magic and various magic objects, they sometimes perceived sticks, goat horns, bells, etc. as the seat of the helping spirit. Interestingly, according to folk tradition there are differences between magic acts performed by male magicians and those performed by female magicians.

The prevailing opinion holds that witches acquired their abilities from the cult of the Great Goddess, a lunar deity from whom the mysterious and orgiastic characteristics of female witchcraft originated. Wizards, on the other hand, preserved more shamanistic 


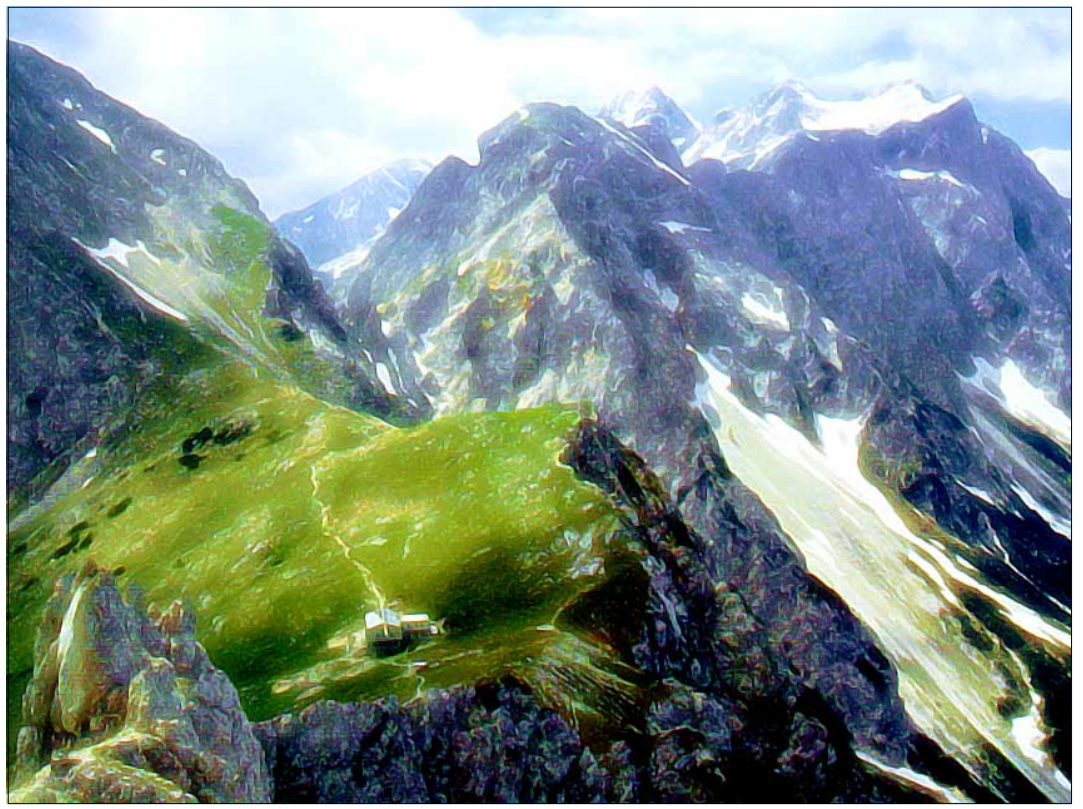

Photo 1. The mountains where Slovenian witches reportedly gather and dance. Photo from Cevc 1997: 54.

elements in their traditions. Since a Shaman was usually a key person in a society, the tradition is believed to have descended from the worship of a certain important deity. Slovene traditions, for instance, mention kresnik 'protector of the clan', whom god gave to mankind in order to protect humanity against the evil that threatened its existence. According to folklore sources, kresniks often fight the evil or evil wizards and witches.

Flying as well as meeting spirits is generally understood as a "journey" where the spirit leaves the body behind in a trance-like state and travels around in other worlds, coming into contact with ghosts and spirits of the dead. People used to say that witches go to dance on Klek or some other mountain, for instance Slivnica, Grintavec, Rogaška. One widespread belief maintained that at midnight witches fly to a mountain on birch-brooms and gather among hazel trees where they are sometimes perceived as shining lights. According to popular belief, demons encountered by witches and wizards on such 
journeys - or demons that practitioners of magic invoked at crossroads, in a magic circle, at home at midnight, etc. - acted as their assistants. People also believed that witches danced in whirlwinds or that wind gusts carried hail-making witches, sometimes depositing them in a nearby brook.

In addition to belief records, many magical actions were recorded. Among other things, witches and wizards were believed to use their magic to change the weather - conjure or prevent hail, thunderstorms, or strong wind. According to mainly older sources, they performed magic by imitating the natural phenomenon in question: linen, for instance, represented fog or clouds, a matchs lightening, etc. Also, thunderstorms were often driven away with a blessed bell, holy water, cannon shot and the like.

A lot has been recorded in connection with the emergence and disappearance of disease, as sorcerers were also believed to be able to turn cows barren or cause sickness in people and animals. Tradition also reflects people's fear for cattle and field curses. If they wanted to steal milk from a cow they took a shepherd's rope and "milked" it by pulling it from both ends, while uttering strange words. Fields, where sorcerers buried something, did not yield crops, vineyards were damaged if they buried quicksilver in them. They also knew how to move crops to their own field. If the night before Whitsunday was dewy, witches, wrapped in sheets, would roam wheat fields and wring the wet sheet over their own field, thereby taking the wheat. Likewise, on Sundays after the new moon they would drag sheets over hedges and pastures before the sunrise, acquiring the wealth of others. They could also unearth money where "a treasure bloomed", as they said.

Sickness was healed in different ways, often by beseeching, adjuring, conjuring and praying. Invocations against spells, sprains, snake bites, St. Anthony's fire, swelling and a number of other illnesses have been recorded. The healing process could involve numerous other healing practices and expedients - water and herbs were of special importance. 
Magic and charms were an important part of easing interpersonal relations. Love magic was diverse, including a number of procedures: a girl had to boil the lover's hair to make him come to her,or prepare love potions. Flowers were used for predicting the future, and elder was used to foretell the future husband, etc.

\section{CHARMS IN PRACTICE}

After this brief and generalized tour of magical practices in Slovenia, let us proceed to the charms or invocation practices in Carinthia, especially in borderlands, where these ways of healing are still practiced today.

Invocations are nowadays generally performed at home. Healers use different herbal concoctions and agents - objects such as a towel, for instance, which is placed on the sore part of the body and kept there until the spot is healed.

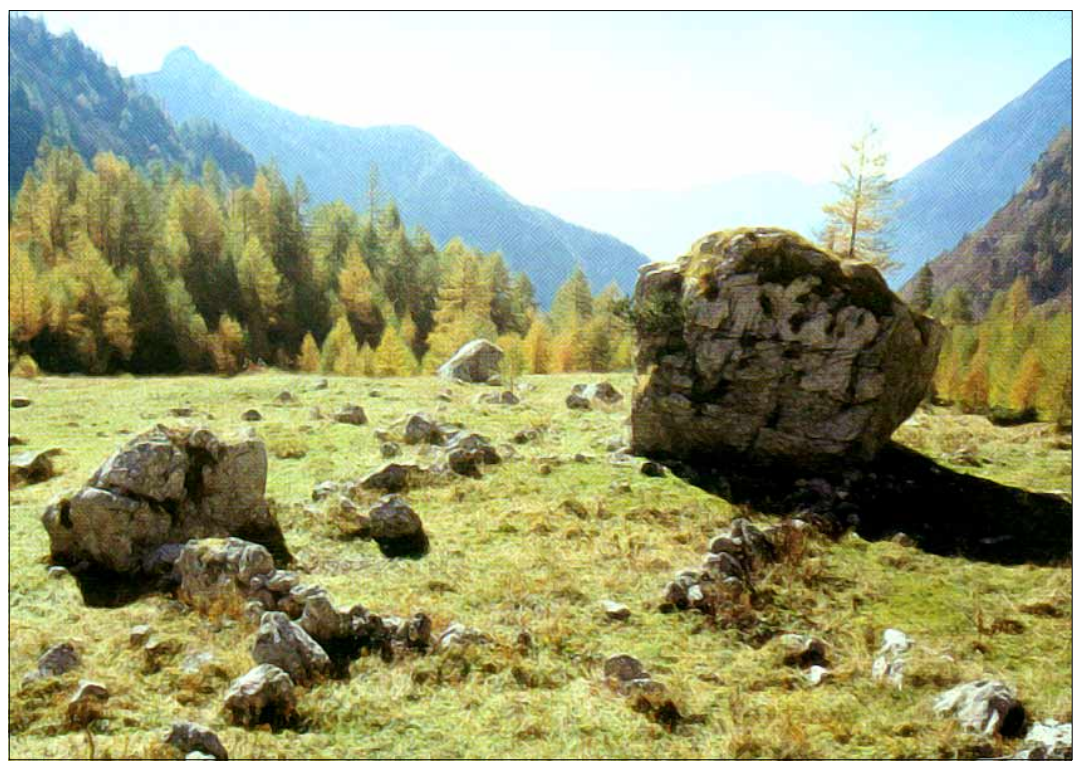

Photo 2. Another typical view in the Slovenian mountains. Photo from Cevc 1997: 55. 
In addition, healers may possess divinational abilities and a gift of premonition. In their dreams they may foresee an event which will happen in the future. They can also predict danger or recognize signs predicting an accident, death, etc.

My main informant, Marija, is from the area of Slovenji Plajberg in Carinthia on the northern slope of the Karavanken Mountains in the Alps near the Ljubelj (Loibel) mountain pass on the border between Austria and Slovenia. Several hundred people living in the area are engaged with agriculture, cattle-breeding, work as lumberjacks, but, since the last lead mine in the vicinity closed down in 1904 , people work mainly in nearby towns.

Marija acquired her magic skills from her parents. Feeling that she possessed a gift for this kind of work, young Marija became interested in the skills of folk sages, the healing power of plants, invocations, and learned from the magic book of spells - Kolomonov Žegen. She also took interest in objects used in magic acts: bells, holy water, fire, herbs, etc.

Marija knows several invocations for healing different illnesses and other ailments such as sprains, consumption, or cramps. Invocations are accompanied by non-verbal healing rituals. For instance, a sick person comes to her with a towel, she folds it and places it upon the painful place. Upon leaving he takes the towel with him; it supposedly helps to heal. As Marija herself said, such healing acts are successful "for those who believe in it."

Marija owns a bell which has been handed down from one generation to another. She inherited it from her father-in-law, a wiseman who could heal animals and people. The bell is said to have been purchased and blessed at Višarje, a pilgrimage destination, two hundred years ago. Marija most often uses the bell to ward off thunderstorms and hail. She says:

Unless I am too late when black fog covers the Vranca Mountain and Žingarca Mountain, I can drive it away. I chime the bell, sprinkle holy water, then make a fire and pour a spoonful of holy water into it, adding flowers. Then I chant this prayer: 
There is a fog, there is a mist,

And the Holy Trinity among them.

Whoever is stronger

Can go ahead and try us.

Then I make the sign of the cross and say: God the Father, help, God the Son, help, God and the Holy Ghost, help.

The napkin that covered the basket of offerings taken to church on Easter is also said to help to drive away thunderstorms. The napkin should not be washed. When a storm is nearing, the napkin is draped over a fence and the storm goes away. Marija continues: "Sometimes people would take a rake, a fork, and a scythe and place them under the waterspout. This drives away the hail." Different manners of sorcery can therefore achieve the same objective. It is the power of energies that is of greatest importance.

When performing the ritual of invocation, Marija often uses a kerchief. She twists it into a plait, places both hands upon it, and utters a corresponding charm over it. The kerchief is then given to the patient who wraps it around the sore spot when needed. A kerchief is very often used for healing afflicted animals since Marija does not heal them by placing her hands upon them.

For warding off thunderstorms or other weather calamities, Marija uses the little blessed bell, the family heirloom. For chasing away storms she also uses a napkin blessed in church on Easter Saturday; also, ashes blessed in church on Ash Wednesday drive away strong winds when scattered against the wind. Hail or thunderstorms could not damage a field if holy water has been poured on three of its corners.

\section{CLASSIFICATION OF HEALING CHARMS}

The ritual of performing an invocation is made up of several elements, all of which serve to restore the natural order of things. Of special importance is the right time: moon phases can greatly affect the outcome of a ritual, hastening or impeding the healing process. Friday, for instance, is the day best suited for this kind of work. Especially appropriate is night-time, but also noon, early morning before sunrise, or eventide. It was believed that magic was espe- 
cially potent on St. George's Day, on the night before Pentecost Sunday, on Midsummer Day, and during Ember Week.

In Slovenia, charms are verbal magic formulas using subtraction, exorcism, analogous magic, mythical numbers, repetition, as well as elements or parts of myths, parables and other narratives. Based on written source and my personal experience, charms can be classified into the following ten groups:

\section{Formulas driving the affliction away to a faraway place}

Charms against rheumatism, gout, joint ailments:

In the name of the Father, the Son, and the Holy Ghost! Amen. You, who are the cause of rheumatism, Who dry up blood and Flesh!

I command you

In the name of the Father, the Son and the Holy Ghost, In the name of the Holy Trinity,

To leave these bones,

To leave these joints,

To leave this blessed, baptized, confirmed body,

And go to high mountains,

To deep gorges,

Where no blessing can reach you,

Where no bell tolls,

Where no rooster crows,

Go and dig and rout around!

Help me, Father, Son, and the Holy Ghost,

The Holy Trinity, Virgin Mary, you white blossom,

The holy baptizing patroness,

The five holy, bleeding wounds of Christ, and St. Valentine.

Say the Lord's Prayer 3 times,

Repeat it 3 times.

(Wieser)

Snake bones are also used to drive away rheumatism. A dead snake is placed into a box with holes, and the box on an anthill. When the ants have picked the bones, the bones are thrown on coals. A rag is first held above the coals, then placed upon the afflicted part of the body. 
Charms against bone tuberculosis:

Go to a maple tree,

From the maple to a leaf,

From the leaf to a mountain,

Where no bell tolls,

No chair stands,

No butt sits,

No fire cooks,

No mouth eats.

There you stay, this is not where you belong!

I beseech you in the name of the Father, the Son and the Holy

Ghost.

(Košir \& Möderndorfer 1926: 90)

\section{Formulas prohibiting a person to cause harm}

Charms against gout, rheumatism:

Throw a pebble from a brook into a pot, pour scalding water over $i t$, place the pot on the afflicted area.

On Easter morning Jesus Christ rose early,

Took a golden stick and left to roam the world.

He met gouts and rheumatisms,

And asked them: "Where are you headed?"

They replied: "We're off to dig out so-and-so's bones, to twist his limbs,

to place his body into the blackened sod."

Jesus said:

"You have no right to dig out so-and-so's bones, to twist his limbs, to place his body into the blackened sod.

Off you go to high mountains,

Where no worm lives,

Where no rooster crows,

And be devoured by black fog."

Help me, Father, Son and the Holy Ghost.

(Košir \& Möderndorfer 1926: 98) 


\section{Ordering the culprit to take the poison back}

Charms against poison:

Poison, I beseech you in this act, Asking for help St. Urh and St. Margaret. Beseeching you in front of the living God To take back the poison of all poisonous animals. If you are no longer alive, your kin has to take it back for you. Make the sign of the cross, blow onto bread and stab it three times with a knife. Say the Lord's Prayer, Revered Mary. (Križnik)

There is a holy mountain, there is a holy chair.

St. Šmpas is sitting on the chair,

Holding a holy sword in his hands.

Virgin Mary comes to him,

Holding the merciful Jesus in her hands, and says:

"Why do you not drive away this poison and the animal from which it had come?

Chase away the poison back into the animal from which it came!" Say the Lord's Prayer in honour of St. Šmpas for three times over a piece of bread, give the bread to the animal.

(Dolenc)

\section{Supplication to heal the afflicted tissue}

Charms for meniscus, knees, back, cattle:

Jesus and St. Peter

Were crossing a footbridge.

When St. Peter broke his leg

Jesus spoke these words:

"Blood to blood,

Vein to vein,

Sinew to sinew,

Bone to bone,

Flesh to flesh,

Skin to skin. 
Make the sign of the cross: help us, Father, help us, Son, help us, the Holy Ghost. Say the Lord's Prayer three times.

(Wieser)

\section{Narration of an analogous magic act}

Charms against fire:

This water shall put out this fire

Just like by the Jordan brook

John the Baptist baptized Jesus,

Putting out a big fire.

(Križnik)

St. Agnes, St. Sebastian and St. Florian,

Carry the water,

Extinguish the fire!

In the name of the Father, the Son and the Holy Ghost.

(Dolenc)

\section{Formulas of cessation}

Charms against bleeding:

Grandpa a miller, father a miller, son a miller.

Just as these three millers shall stop at the heavenly gate,

You shall stop bleeding!

Help us, Father, Son and the Holy Ghost.

(Košir \& Möderndorfer 1926: 104)

\section{Formulas of subtraction}

Charms against swelling:

How many swellings are there?

Are there nine,

Not nine, but eight,

Not eight, but seven [---]

(Košir \& Möderndorfer 1926: 101) 


\section{Supplications to ease pains}

Charms against cramp:

The right side of Jesus,

Which had been pierced,

Bled blood and water.

Please cleanse all this pain,

Hide it within your holy wounds!

Make the sign of the cross three times: Help us, Father, Son and the Holy Ghost, Help us, Virgin Mary, our dear flower.

(Wieser)

\section{Narration of parables}

Charms for healing a broken bone or a sprain:

While St. Florian was grazing his horse

He fell over a rock,

Spraining his ankle.

He called to the Father, the Son and the Holy Ghost:

"Please help heal my poor leg!"

Lo and behold, he jumped up,

And his leg was healed.

(Košir\& Möderndorfer 1926: 109)

\section{Formulas asking for the saints' help}

Charms against gout:

All the Lord's saints,

I beg you to help this man,

In the name of St. Florian, St. Sebastian, St. Urh,

I firmly believe that God is almighty,

That my plea shall help.

I beseech you, gout,

In the name of the Father, the Son and the Holy Ghost. (Križnik)

The strength of words and thoughts in charms, supplications, oaths, prayers, exorcist formulas, etc., is obvious. The charms - at least in their structure and concept - do not differ much from nation to 
nation. The reason for this seems to lie in the common origin of charms, the common archetypes. Already Egyptian Hermetic writings contained charms, and similar charms are found in different magic books such as the so-called Kolomon Book of Charms ("Kolomonov Žegen"), Defence of the Spirit ("Duhovna bramba"), and others. However, since different societies adhered to different concepts of the world there are differences despite the kindred sources and remarkable differences in the age of invocation formulae. Although different social and cultural groups have imbued these formulas to a considerable extent with local elements, there is an universal layer of elements as well as an easily detectable relation between local myths and cosmological beliefs, and between both charms and myths of different nations.

\section{COSMOLOGICAL PRINCIPLES AS REFLECTED IN CHARMS}

The cosmological concept of the world has three parts, reflecting people's notions about the threefold nature of the world. There is the underground world with its snakes, dragons and devils. The sphere that is (usually) invisible to people surrounds the earth and is the home of numerous creatures like fairies and demons. The celestial world is populated with gods, the ancient Slavic supreme gods - Perun and Veles - are still dimly present in people's minds while old pagan deities have long ago been replaced by the Holy Trinity. Similar changes have taken place in addition to narratives also in charms, where Pagan gods have been replaced with Christian saints or the Holy Trinity.

The cosmological concept in Slovene charms follows the old scheme of the cosmic order: land, water, the tree of life and the cosmic mountain. The cosmic mountain has been placed linearly behind the land, the water and the tree. The vertical concept of cosmos is expressed by the world tree or the cosmic mountain. Similar cosmological structures can be found in some folk songs, e.g. the cycle of tales about Kralj Matjaž 'King Mathias' - a Central European parallel of the legend of King Arthur, which is strongly based on the notions of the tree of life and the cosmic mountain. 
According to one variant of the legend, King Mathias and his army are asleep in a cave under the Peca mountain. Some day, King Mathias will awaken. In the middle of winter, a green linden tree shall grow in front of the cave. It will bloom ravishingly at midnight for one hour, and then will dry up. On St. George's Day (April 23), King Mathias will hang his shield on it, whereupon the tree will grow green again. Mathias and his army will then reappear, defeat all enemies and start the golden era.

This legend follows the cosmological concept of time and space. King Mathias is now resting under the Peca mountain, and Peca can be compared to Golgotha. A tree grew from the bones of Adam, who was buried underneath, on Golgotha. Jesus Christ has been depicted crucified on the tree of life on the Golgotha mountain. The motif of the tree - the tree of life - can also be compared to the motif of the saviour in the cradle, and the legend of the cross. In front of King Mathias's cave there grows another tree, a tree which turns green and blooms in winter. It has been prophesised that in a time of hardship King Mathias shall reappear and the golden era will begin anew, just as Adam shall rise from the dead on Judgement Day. Comparing these legends to charms, it is obvious that this type of cosmological concepts of the world occupies an important role in both genres. The tree of life and the cosmic mountain are frequent allegories in charms.

The second, equally obvious parallel between the cosmological concepts which are recognizable in charms as well as in folk tales is the myth about the Dragon Slayer. The very concept of charms is summarised in the battle between good and evil, as has already been pointed out by several other researchers, like V. Toporov and V. Ivanov (Toporov \& Ivanov 1974), L. Radenković (1996), S. G. Šindin (1999) and N. Mikhailov (1972).

We can glean from the above that faith in the supernatural to heal, prevent, and solve difficulties is still alive, especially in rural regions. The same is true for the use of magic acts for achieving this purpose. What is different from older records, at least in the areas discussed in this paper - but probably also in the rural parts of Slovenia at present - is that today positive magic, namely the one used to heal, prevails. 


\section{References}

Bošković-Stulli, Maja 1991-1992. Hexensagen und Hexenprozesse in Kroatien (Tales about witches and trials for witchcraft in Croatia). Acta Ethnographica Academiae Scientiarum Hungaricae 37, Nos. 1-4, Budapest, pp. 143-171.

Cevc, Tone 1997. Davne sledi človeka v Kamniških Alpah. Ljubljana: Znanstveno raziskovalni center SAZU.

Dapit, Roberto 2000. Il motivo del Salvatore nella culla in racconto popolare resiano. Studia mythologica Slavica 3. Ljubljana-Udine, pp. 161172.

Dapit, Roberto 2001. Moè besede, moè prednikov. Zagovorni obrazci v Reziji in drugje. Studia mythologica Slavica 4. Ljubljana-Udine.

Dolenc $=$ Dolenc, Milan 1976. Katalog zelišènih zdravil, rokopisnih ljudskih medicinskih bukev in medicinskih zapisov [The catalogue of medicinal herbs, manuscript books on medicine and medical notes]. Manuscript in NUK (Narodna in univerzitetna knjiznica). Ljubljana.

Dolenc, Milan 1999. Zagovori v slovenski ljudski medicini. Zvonka Zupaniè Slavec \& Marija Makaroviè (eds., comp.). Ljubljana.

Graber, Georg 1941. Sagen aus Kärnten [Folk tales from Carinthia]. Graz: Leykam.

Grabner, Elfride 1986. Grundzüge einer ostalpinen Volksmedizin. Mitteilungen des Institutes für Gegenwartsvolkskunde 16, $457 \mathrm{Bd}$. Wien: Verlag der Österreichische Akademie der Wissenschaften.

Ivanov, Viacheslav \& Toporov, Vladimir 1974. Issledovania v oblasti slavianskikh drevnostei: Leksicheskie i frazeologicheskie voprosi rekonstruktsii tekstov [About Ancient Slavic: Lexicological and Phraseological Questions Regarding Text Reconstruction]. Moskva.

Kelemina, Jakob 1930. Bajke in pripovedke slovenskega ljudstva [Myths and Tales of Slovenian People]. Celje.

Košir, Pavel \& Möderndorfer, Vinko 1926. Ljudska medicina med koroškimi Slovenci [Folk Medicine among Slovenes in Carinthia]. Časopis za zgodovino in narodopisje 21. Maribor.

Koštial, Ivan 1911. Sieben Beschwörungsformeln aus dem slowenischen Teile des Küstenlandes. Zeitschrift für österreichische Volkskunde XVII. Wien.

Kotnik, France 1924. Storije. Koroške narodne pripovedke in pravljice [Stories. Carinthian folk tales and fairy tales]. Prevalje.

Kotnik, France 1952. Iz ljudske medicine [From the folk medicine]. Narodopisje Slovencev II. Ljubljana, pp. 122-133.

Krainz, Johann (comp.) 1880. Mythen und Sagen aus dem Steirischen Hochlande. Graz: Bruck.

Krek, Gregor 1887. Einleitung in die slavische Literaturgeschichte: akademische Vorlesungen, Studien und kritische Streifzüge. Akademische 
Vorlesungen, Studien und kritische Streifzüge. Graz:Verlag von Leuschner \& Lubensky, K. K. Universitäts-Buchhandlung.

Kühar, Stevan 1911. Narodno blago vogrskij Slovencov [Folklore of Slovenian people in Hungary]. Časopis za zgodovino in narodopisje 8. Maribor, pp. 47-76.

Kuret, Niko 1997. Opuscula selecta. Poglavja iz ljudske kulture [Opuscula selecta. Chapters from Folk Culture]. Ljubljana: Slovenska Akademija Znanosti in Umetnosti.

Maikov, Leonid N. 1994. Velikorusskie zaklinania. Sbornik. Sankt Peterburg: Evropeiskii Dom.

Matičetov, Milko 1956. La costola di legno. Di un tema narrativo diffuso nel territorio alpino orientale [The wooden rib. On the motif spread through the territory of the Eastern Alps]. Alpes orientales 1, SAZU 2. cl., Dela 12. Ljubljana, pp. 79-90.

Matičetov, Milko 1961. Uno scongiuro sloveno contro la nebbia e i suoi corrispondenti svizzeri. Alpes Orientales III. Basel, pp. 160-163.

Mikhailov, Nikolai 1972. K rekonstruktsii otdelnykh kosmogonicheskikh / kosmologicheskih i "antropologicheskikh" fragmentov slavianskoi modeli mira na materiale russkikh zagovorov. Studies in Slavic Folklore and Folk Culture 2. Berkeley Slavic Specialities, Oakland, CA, pp. 57-76.

Möderndorfer, Vinko 1946. Koro ške narodne pripovedke [Carinthian folk tales]. Celje.

Möderndorfer, Vinko \& Šašel, Josip 1972. Koroške pripovedke. Ljubljana.

Navratil, Ivan 1885, 1886, 1887, 1888, 1890, 1892, 1894, 1896. Slovenske narodne vraže in prazne vere [Slovenian folk superstitions]. Letopis Matice slovenske. Ljubljana.

Owen, Davies 1996. Healing Charms in Use in England and Wales 1700-1950. Folklore 107. London, pp. 19-32.

Pajek, Josip 1884. Črtice iz duševnega žitka štaj. Slovencev [Sketches from Folklore of Styrian Slovenes]. Ljubljana.

Pócs, Eva 1999. Between the Living and the Dead.A Perspective on Witches and Seers in the Early modern Age. Budapest: Central European University Press.

Poznanski, N. 1995 [1917].Zagovory: opyt issledovanija proischozdenija i razvitija zagovornych formul. Reprint. Moskva: Indrik.

Radenković, Ljubinko 1996. Narodna bajanja kod južnih Slovena $=$ South slavic folk incantations. Beograd: Prosveta.

Šašel, Josip \& Ramovš, Fran 1936. Narodno blago iz Roža. Maribor.

Shindin, Sergei 1999. Ob odnom vozmozhnom vostochnoslavianskom "protorituale" (na materiale zagovornoi traditsii). Studia mythologica Slavica 2. Ljubljana-Udine, pp. 245-258.

Tambiah, Stanley Jeyaraja 1995. Il potere magico delle parole, Rituali e cultura. Bologna. 
Toporov, Vladimir N. 1993. Ob indoevropeiskoi zagovornoi traditsii. Issledovania v oblasti baltoslavianskoi dukhovnoi kulturi:Zagovor. Moskva.

Vukanović, Tatomir P. 1989. Witchcraft in the Central Balkans. I: Characteristics of Witches; II: Protection against Witches. Folklore 100. London, pp. 9-24; 221-236.

Zablatnik, Pavel 1972. Iz ljudske medicine pri koroških Slovencih. Traditiones I. Ljubljana, pp. 181-185.

Kropej, Monika 2001. Karel Štrekelj. Iz vrelcev besedne ustvarjalnosti [Karel Štrekelj. From the Springs of Poetics]. Sonderdruck aus: Traditiones 24 (1995) 25-48. Ljubljana.

\section{Manuscript sources}

Križnik = Križnik Gašpar. Manuscript from 1872 in the Archive of the Institute of Slovenian Ethnology, Scientific Research Centre of the Slovenian Academy of Sciences and Arts, Ljubljana: ŠZ 1/25. Published: Kropej 2001.

Kropej, Monika. Slovenji Plajberk, Tape 1999, Archives ISN ZRC SAZU, Ljubljana.

Makarovič (Jagodic), Marija: Črneča vas na Dolenjskem [Črneča village in Lower Carniola], 1956, Archives ISN ZRC SAZU, Ljubljana.

Šelovin, Pavel. Črtice iz Sežane in okolice [Folklore from Sežana and the surroundings], 1964, Archives ISN ZRC SAZU, Ljubljana.

Wieser. Tape recordings of Maria Wieser by Monika Kropej. Carinthia, 1996-2001. Archive of the Institute of Slovenian Ethnology, Scientific Research Centre of the Slovenian Academy of Sciences and Arts, Ljubljana. 